\title{
土木学会木材利用ライブラリ 「木橋の耐用年数」について
}

渡辺浩*

\section{1.はじめに}

土木分野は，建築分野と共に市民の財産を形づ くる役割を担っている。その性質上，両分野とも に大量の建設資材が必要とされ，かつては木材が その主流を占めてきた。近年では木材の位置づけ は低下しているが，それでもなお大口の需要を有 しており，木材資源の利用拡大を進める上でも重 要な立場にある。

両分野の違いを一言で表せば，公共事業主体か 民間事業主体か，また屋外利用主体か屋内利用主 体かである。すなわち土木分野では，屋外利用が 主体であるために常に耐久性という課題と向き合 わなければならない。さらに，公共事業であるた め耐久性の課題は看過できない。結果として高度 成長期以降の脱木材化には積極的で，近年の木材 利用ルネサンスにおいては著しく腰が重い状況を 呈している。

土木分野における木材利用量は，現状では建築 分野の $1 / 20$ 程度に留まっている。しかしながら, 構造物のスケールは大きく適用範囲も広い。また, 強度や形状，見た目等が問題になるものからなら ないものまで多様な利用法がある。つまり土木分 野には木材に対する非常に大きな潜在需要がある と言える。

このような観点から土木学会では2009年に木材 工学特別委員会が設置され，土木分野における木 材利用の啓蒙と諸課題の検討に取り組んできた。 ここでは，あわせて研究成果を木材利用ライブラ リとして公開し周知を図っている。このライブラ リは2011年 9 月の「1 土木分野における木材利用
入門 〜土木分野における環境貢献に向けて〜」

以降，現在までに5編がリリースされている。 本報告では，このうち2011年11月に発刊された

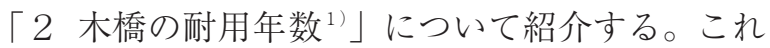
は, 同時期に活動が終了した木橋研究小委員会 (委 員長：平沢秀之 函館工業高等専門学校教授）の 成果報告としてとりまとめられたものである。な お, 誌面の都合上, ここではその概要のみを示す。 ライブラリ本文は委員会ホームページ（http:// tbl.tec.fukuoka-u.ac.jp/jsce-wood/lib/）からダウ ンロードできるので，そちらを参照されたい。

\section{2. 取り組みの背景}

土木分野でもかつては木材が多く使用されてお り，木橋も特別な存在ではなかった。その土木学 会において初めて木橋を対象にした委員会が設置 されたのは1993年であった。この頃，大断面集成 材や高耐久性をうたう輸入木材による大型の木橋 が相次いで架けられていたが，建築技術や海外の 技術を準用した一部の木橋では，橋としての当然 の性能を備えていないものも見られた。そのため, 技術研究から実践サポートまで通常の委員会活動 の域を超えた幅広い活動が進められた。それらの 成果は2005年に発刊された「木橋技術の手引き 2005」にとりまとめられたが，ここでもいくつか の課題が残された。そのひとつが，木橋の耐用年 数である。

現在供用中の鋼橋やコンクリート橋の耐用年数 は明確には規定されていないが，おおむね50年程 度と解釈されている。しかし木橋にとって50年は 容易ではない。また, 木橋では構造形式や周辺環

*福岡大学工学部社会デザイン工学科 
境, 維持管理の状況によっても期待できる耐用年 数は大きく変化するが，それらの因子がどの程度 の影響を及ぼすかは知られていない。また，お扮 まかであっても妥当な耐用年数を知ることができ れば，今後を見据えた対策を検討できるという点 でも有益である。そこで本ライブラリでは，木橋 の材料や構造, 周辺環境, 維持管理をパラメータ とした木橋の一般的な耐用年数の推定法を提案 し，実例と比較してその検証を行っている。

\section{3. 耐用年数の推定法}

\section{(1) 概要}

耐用年数を予測するため, 式(1)で得られる $\mathrm{Y}$ を求める。ここで $\mathrm{P}, \mathrm{E}, \mathrm{S}, \mathrm{D}, \mathrm{C}, \mathrm{M}$ は表 1 に 示す影響要因を数值化したものである。ただし, ここでは耐用年数に影響を与える因子として主構 造材の腐朽等による劣化のみを考慮している。

$Y=P \times E \times S \times D \times C+M$

\section{(2) 使用材料}

樹種固有の心材耐久性と, 防腐処理に関する方 法と薬剤浸透性を考慮するものである。このうち 素材の耐朽性と薬剤浸透性については木材保存学 入門扮ける区分を数值化している。また, 薬剤が 適切に加圧注入された部材では比較的長期の耐久 性が期待できることから，それが反映されるよう な式としている。

\section{（3）周辺環境}

耐用年数は架橋位置の環境に大きな影響を受け る。このうち, 架橋位置の気象条件が耐用年数に 与える影響として, 気温が $15^{\circ} \mathrm{C}$ となる積算時間 により $\mathrm{e}_{1}$ に0.8から 1.2 の点数を与える。気温のデー 夕は架橋地点の最寄りのアメダスのデー夕，また は年平均気温との比を利用するとよい。また局所 的な湿潤環境に置かれる場合 $\mathrm{e}_{2} に 0.7$ 与えこれ を考慮している。

\section{(4) 構造形式}

劣化の原因となる水分は主に雨水に起因するた め, 屋根が設置された橋は一般に耐用年数が高い。 これを考慮するのが $\mathrm{s}_{1}$ である。また, 床面が同 様な役割を果たすことができる上路橋でもその効 果が見られることから， $\mathrm{s}_{2} に よ り$ 考慮する。

橋梁の形式そのものも耐用年数に大きく関わ る。これを $\mathrm{s}_{3}$ とて考慮している。例えばトラ ス橋では接合箇所が多く, その劣化が全体構造に 致命的な影響を与えやすいことから最も低い点数 としている。これに対して桁橋では，そのような 接合箇所が少なく, 構造的な圥長性も高いため, 最も高い点数としている。また, 鋼床版やコンク リート床版ではその劣化が主構造材に与える影響 が小さいこと, また防水型の舗装がなされれば床 組構造に与える影響は小さいことから, これらを $\mathrm{S}_{4}$ で考慮する。

\section{表 1 影響要因とその構成要素}

\begin{tabular}{|c|c|c|}
\hline 影響要因 & & 各要因の構成要素と概要 \\
\hline \multirow{3}{*}{$\begin{array}{l}\text { 使用材料 } \\
P=p_{1}+p_{2} \times p_{3}\end{array}$} & $p_{1}$ & 素材としての耐朽性（樹種により $0.8,0.9, \quad 1.0,1.5 ）$ \\
\hline & $p_{2}$ & 防腐剤の浸透性（樹種により $0.8,0.9,1.0,1.1 ）$ \\
\hline & $p_{3}$ & 防腐処理の方法（注入・表面処理の有無により 1.0， $0.6 ， 0.3 ， 0 ）$ \\
\hline \multirow{2}{*}{$\begin{array}{l}\text { 周辺環境 } \\
E=e_{1} \times e_{2}\end{array}$} & $e_{1}$ & 架橋位置の地域的な環境条件 $(0.8,0.9, \quad 1.0,1.1,1.2)$ \\
\hline & $e_{2}$ & 架橋位置の局所的な環境条件 (0.7, 1.0$)$ \\
\hline \multirow{4}{*}{$\begin{array}{l}\text { 構造形式 } \\
S=S_{1} \times S_{2} \times S_{3} \times S_{4}\end{array}$} & $s_{1}$ & 屋根の有無 $(2.0,1.0)$ \\
\hline & $S_{2}$ & 上路·中路·下路式の区分 $\left(\begin{array}{lll}1.0, & 0.8, & 0.8)\end{array}\right.$ \\
\hline & $S_{3}$ & 桁橋, アーチ・ラーメン橋, 床版橋, トラス橋 $(1.0,0.9,0.8,0.7)$ \\
\hline & $S_{4}$ & 床版の種類と舗装の有無（1.8, 1.5, 1.0） \\
\hline $\begin{array}{l}\text { 腐朽防止（構造） } \\
D=d\end{array}$ & $d$ & 桁覆や接合部の水仕舞い方法等（1.0, 1.3） \\
\hline $\begin{array}{l}\text { 腐朽防止（施工） } \\
C=c\end{array}$ & $c$ & 後加工部の防腐等の現場対応（1.0, 1.2） \\
\hline \multirow{2}{*}{$\begin{array}{l}\text { 保全行為 } \\
M=\sum(n \times m)\end{array}$} & $n$ & 保全行為の回数 \\
\hline & $m$ & 再塗装や腐朽箇所の補修等ごとに $(0.3)$ \\
\hline
\end{tabular}




\section{(5) 劣化防止の工夫}

適切な雨水対策により耐久性は向上する。この ため古来から様々な工夫がなされてきたが, 近年 の橋ではそれらが見られないものも多い。ここで は桁覆の設置, 部材相互を密着させない工夫, 排 水勾配の確保, 排水装置の設置, 橋座等の劣化対 策等により考慮されていれば, d を割り増すこと によりこれを考慮する。

また，運搬や仮置き時に扔ける雨水の浸入も耐 久性に影響を与える。ボルト孔等の後加工部の処 理も重要である。これらについて特に配慮されて いる場合は，cを割り増すことによりこれを考慮 する。

\section{(6) 保全行為の影響}

木橋に限らず, 適切な維持管理は橋の耐用年数 を延ばす効果がある。ここでの維持管理は, 劣化 に対する適切な対応に加え予防的な保全行為も想 定している。それらは内容のみならずそのタイミ ングによっても効果に違いが生じるが，ここでは 単に保全行為の回数により考慮している。

\section{4. 予測式の検証}

提案されている予測式では,「主材料はスギ, 防腐処理はなし, 平均的な気候, 屋根はなし, 上 路桁橋, 木床版, 特別な劣化対策なし, 標準的な 施工，保全行為なし」という標準的な条件におい て $\mathrm{Y}=1$ となるように定め, この場合の耐用年数 を15年程度と定義している。ただし上限は50年で ある。図 1 は予測耐用年数と Y との関係を示し たものである。

図 1 には，管理者により寿命を全うしたと判断

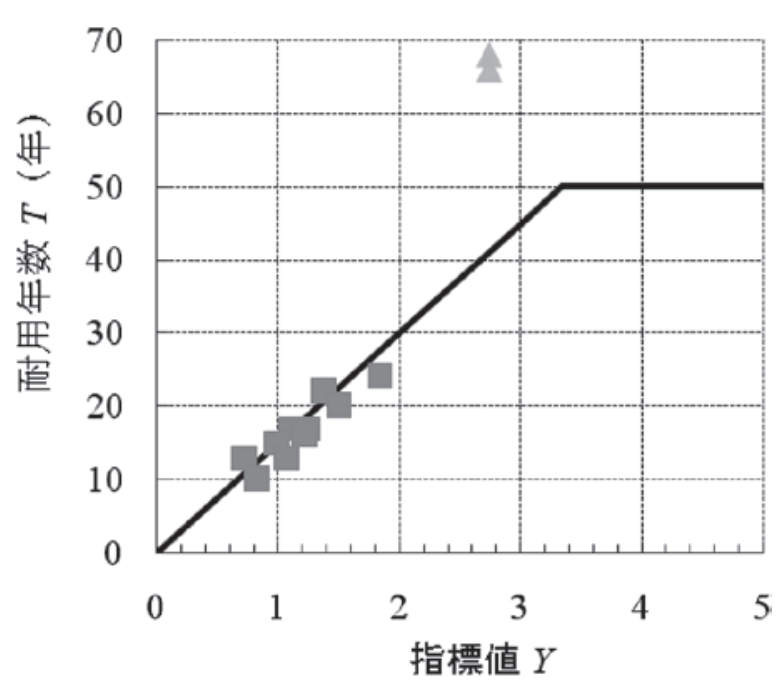

図 1 指標值 $Y$ と耐用年数 $\mathrm{T}$ の関係

された橋の $\mathrm{Y}$ 值と実際の供用年数もプロットさ れている。ただし，設計や施工，保全に関するあ る程度の情報が必要なためプロットは少ない。ま た $\triangle の 2$ 橋は現在も供用中であるが, 構造的な改 変がなされていることから参考值としてプロット している。データが少なく, 供用期間が30年程度 であることから十分な検証がなされたとは言いが たいが，供用年数の目標值を得るという目的では 妥当な予測結果が示されていると言える。

図 2 は供用中の木橋について, 架設からの経過 年数と保全の考慮の有無による耐用年数の予測值 を示している。ここでは,「一部が劣化」と評価 されたものと「健全な状態」と評価されたものの 別にまとめられているが，いずれも予測值は実際 の経過年数を下回って㧍り,「健全な状態」と評価 されたもについてはその差が大きいことから，お おむね妥当な予測が得られていると考えられる。

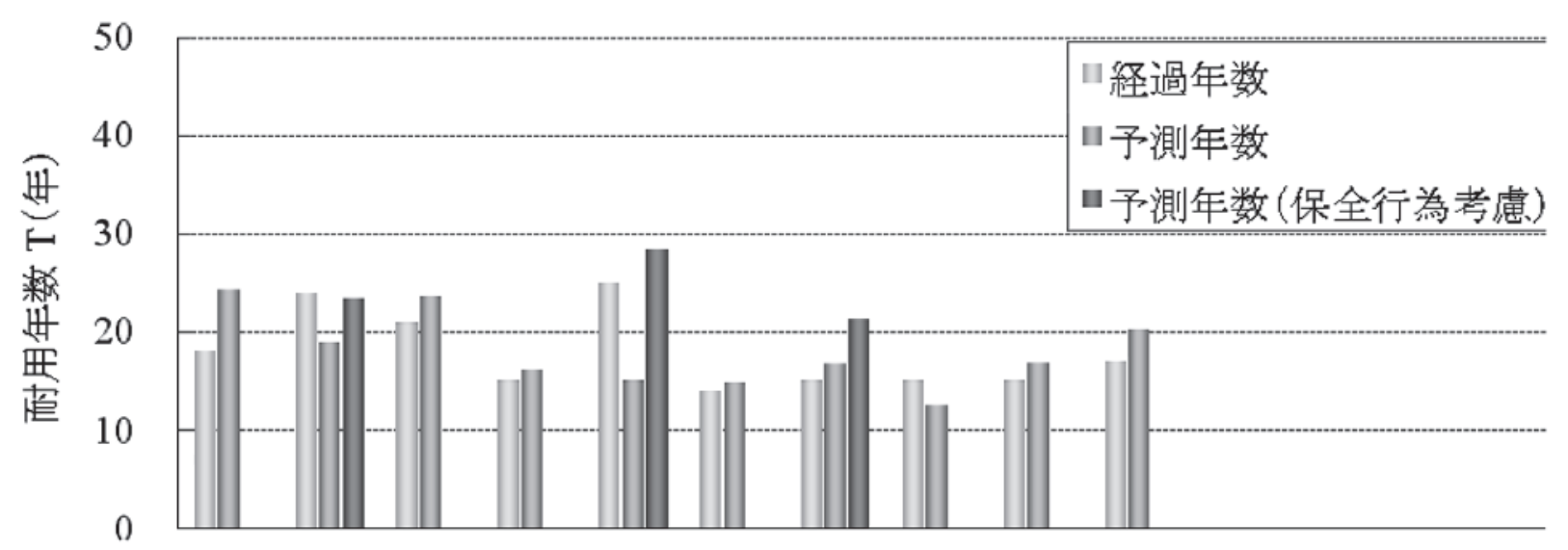

図2「一部が劣化」と評価された供用中の事例への適用 


\section{まとめ}

本文では，土木学会においてリリースされてい る木材利用ライブラリのうち，木橋の耐用年数に ついての研究成果について報告した。今後も研究 を進め，予測精度の向上に努めるとのことである が，現状においても供用中の木橋の長期的な保守 計画を立案する上では有益なデー夕となるであろ う。

土木学会では, 時限措置で 3 年間活動してきた
木材工学特別委員会の研究成果と意義が認めら れ, 今年度より常置委員会の木材工学委員会が設 置されることになった。さらに長期的な視点にお いて, 幅広い研究活動が進められることを期待し たい。

\section{参考文献}

1）土木学会：木材利用ライブラリ 2 木橋の耐 用年数 (2011)

（2012.6 .22受付） 